\title{
Review on Effect of Light on Disease Development and Management of Horticultural Crops under Protected Cultivations
}

\author{
Abebe Assefa $^{1,2 *}$, AmsaluGobena ${ }^{2}$ \\ ${ }^{1}$ Wochamo University College of Agricultural Science, Hossana, Ethiopia \\ ${ }^{2}$ Hawassa university, College of Agriculture, School of Plant and Horticultural Sciences, P.O.B. Box 05, \\ Ethiopia
}

\begin{abstract}
*Corresponding Authors: Abebe Assefa, Wochamo University College of Agricultural Science, Hossana, Ethiopia, Hawassa university, College of Agriculture, School of Plant and Horticultural Sciences, P.O.B. Box 05, Ethiopia
\end{abstract}

\begin{abstract}
This review article aim on effect of light on disease development and management of horticultural crops under protected cultivation. Light is crucial for photosynthesis and plant growth. Living organisms generally harvest the visible electromagnetic spectrum. Light can be used in plant health and quality, the impacts of pests and pathogens can be reduced both as a result of elevated plant resistance and also by direct disruption of pest/pathogen biology. Advances in technology are rapidly exploited by the protected horticulture industry light act us disease development and management. Light affects many aspects of plant biology and many of these responses influence plant resistance to disease. Low red:far- red ratios decrease the production of many secondary metabolites involved in disease resistance. The spores of many plant pathogens are killed by exposure to solar radiation. The different plant species have different light responses, the light responses of different pathogens vary, as do the interactions in different plant/pathogen systems in response to light. Specific wavelengths of light, especially red, blue and green, can induce disease resistance in standing crops against a wide range of phyto pathogens. Spectral quality can have significant effect on plant physiology that could alter plant resistance to microbial challenge. Furthermore, many fungal, bacterial and Viral disease of plants are affected by the spectral quality of the primary light source. Foliar fungal diseases of various crops have been suppressed in green house when UV-A (320-400nm) absorbing viny films were used to cover the structures. The apparent mechanism in disease control was the suppression of spore germination and sporulation of the fungal pathogen caused by extremely low levels of blue or UV-A light. Interestingly, red, blue, and green can induce systemic acquired resistance in various plant species against fungal pathogens. Finally, the light can be useful as a component of an integrated disease management program source in green house conditions.
\end{abstract}

Keywords: Spices, Disease, Light, Light quality, Light duration, Light intensity, Protected horticulture

\section{INTRODUCTION}

Light is crucial for photosynthesis and plant growth. The effects of light on plant growth anddevelopmentarecomplex; theentirespectrumoflightisnotbeneficialforplants.Livingorganismsgeneral lyharvestthevisibleelectromagneticspectrum,Apartfromphotosynthesis, lightalsocontrolsfloweringtime andmorphogenesis. Twomajorphotoreceptors-phytochromes(absorbsred/far-red-light)and crypto chromes (absorbsblue/ultravioletA(UV-A) light) are responsible for plant morphological and developmental changes(Quai et.al,1995 and Deng et.al, 1999 ).Optimal lighting regimes have the potential to increase yields and improve plant quality, nutritional value, and flavor. In addition to enhancement of plant health and quality, the impacts of pests and pathogens can be reduced both as a result of elevated plant resistance and also by direct disruption of pest/pathogen biology (Pearson et al. 2015).

Advances in technology are rapidly exploited by the protected horticulture industry, and have expedited the progression from structures that provide simple frost protection to sophisticated automated plant factories in which all environmental parameters are carefully regulated. Such advances have allowed crops to be produced year-round and can facilitate substantial yield increases.For example, lettuce production in plant factories increased crop yields by up to 100 times per unit area of land compared to conventional outdoor practices (Kozai 2013). As with glasshouse production in light-limited conditions such as winter monthsinnorthern latitudes, crop production in 
plant factories requires artificial lighting. In large-scale plant production systems, the efficiency of the lighting system is key to maintaining profitability. The introduction of LED(light-emitting diodes) lighting systems for horticultural use has attracted considerable attention for their potential to reduce electrical energy inputs, making winter crop production more financially viable. Horticultural LED lighting systems exhibit considerable diversity in their design, control systems, and the light spectra produced. LED lighting systems can be highly energy efficient; however, not all LEDs are more energy efficient than standard high-pressure sodium (HPS) lights (Pearson et al. 2015), and care is needed during design and implementation to ensure that the installed systems meet the needs of the crop production system.

The potential reduction in energy consumption that LED systems can deliver is highly desirable to the horticultural industry. However, the greatest potential of LED lighting systems to alter and improve crop production comes from the tight spectral control that LEDs provide. Light quality influences all aspects of plant biology, and much is known regarding the photo biological processes by which plants sense and respond to the light environment. Manipulation of the light spectrum using LED lighting allows the exploitation of this substantial body of knowledge to achieve improved crop production systems. Optimal lighting regimes have the potential to increase yields and improve plant quality, nutritional value, and flavor. In addition to enhancement of plant health and quality, the impacts of pests and pathogens can be reduced both as a result of elevated plant resistance and also by direct disruption of pest/pathogen biology.

The most appropriate method to control disease is the use of resistance cultivar. However, majority diseases have no resistance cultivar and the manipulation of the greenhouse environment to avoid water dependent pathogen. Use of spectral quality has potential value to control powdery mildew in rose (Suthaparan et al. 2010b) and cucumber (Schuerger, \& Brown.,1997, Shibuya et al. 2011, Wang, H. et al. 2010). Foliar fungal disease of various crops have been suppressed in greenhouse when UV-A(320 to 400nm) absorbing vinyl films were used to cover the structures (Sasaki et al,.1985).The apparent mechanisms in disease control was suppression of spore germination and sporulation of the fungal pathogen caused by extremely low levels of bule or UV-A light (Honda et al., 1977). So that the objective to review the effect of light on disease development and management of horticultural crops under protected cultivations

\section{The Needs of Protected Cultivation}

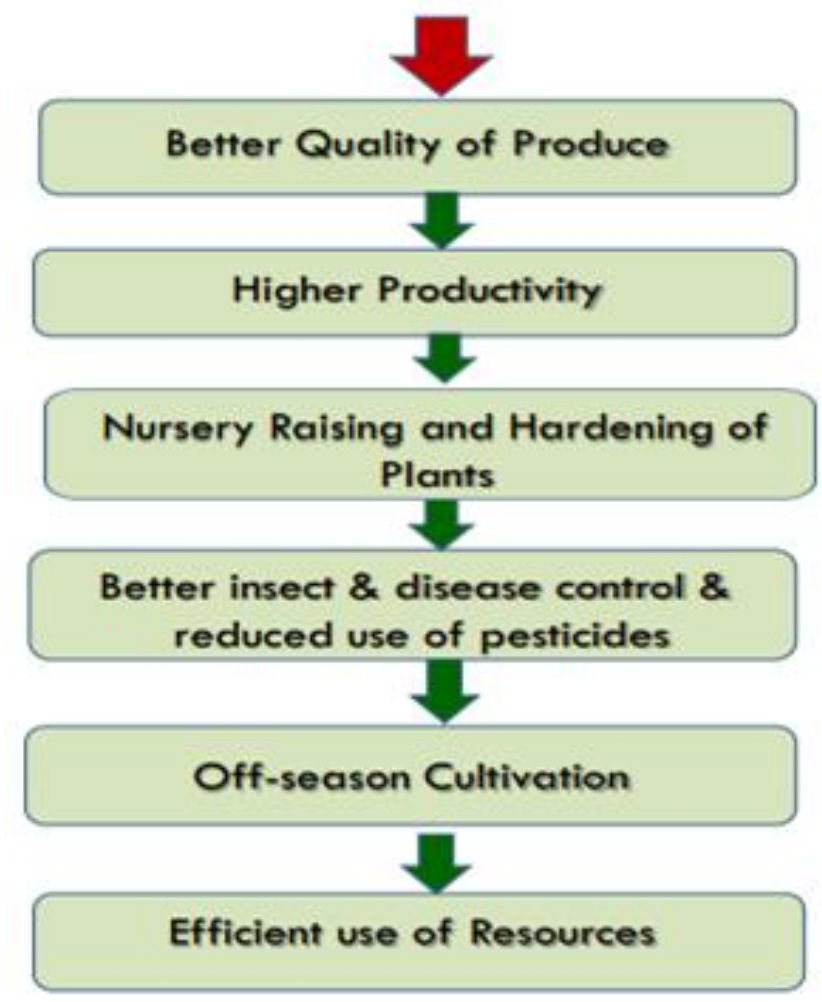

Source: NCPAH, 2014. Work shop on implementation strategy, New Delhi 


\section{Plant Pathogens And their Interactions With Light}

The interactions between plants and their pathogens are also influenced by the light environment. Light affects many aspects of plant biology and many of these responses influence plant resistance to disease. The red:far-red ratio in particular has been shown to influence the expression of many genes, via the phytochromes, that are involved in disease resistance (Griebel and Zeier 2008). Low red:far- red ratios decrease the production of many secondary metabolites involved in disease resistance and thus reduce resistance (Ballaré et al. 2012). Salicylic acid (SA) and jasmonic acid (JA) both play important roles in mediating defenses against pathogens and low red:far-red ratios have been shown to reduce the response of both pathways to disease attack (Daves ,2013).

Light will also have direct effects on fungal pathogens as they also possess an array of photoreceptors that modulate their gene expression (Corrochano, 2007). Fungi have circadian rhythms (Liu and Bell-Pedersen 2006) and certain species sporulate at specific times of day to coincide with events that enable them to infect plants, such as during times when leaves are likely to be wet. Rose powdery mildew (Podosphaerapannosa) was found to release spores during the day and more spores were released with brighter light (Suthaparan et al. 2010). Light color was also important: compared to white light, more spores were released under blue and far-red light, and fewer spores were released under red light. Both day extension and night break light treatments with red light greatly reduced the release of mildew conidia, and such treatments may be useful in reducing the intensity and spread of mildew in crops. As powdery mildews are obligate pathogens, it is not possible to determine if the effect of the light treatments occurs as a direct effect on the pathogen or as a result of the plant responses. However, red light treatments have also been found to increase occurrence of two diseases in broad bean: Alternariatenuissima and Botrytis cinerea (Islam et al. 1998). Spore germination rates were also affected by light color, with blue light reducing germination by $16.5 \%$ compared to other treatments.

The spores of many plant pathogens are killed by exposure to solar radiation (Kanetis et al. 2010), with the UVB component of solar radiation being the most likely to cause spore death. Models of spore germination could be used to define the best time of day to provide a pulse of UV light that would maximize effectiveness. It may also be possible to use novel light strategies to increase disease control. Blue light inhibits spore germination, so if red light only is provided early in the day, spores will germinate and they can then be more easily killed with a UV pulse before the blue light is again turned on (Lekka et al, 2016). UVC light has also been trialed for the control of plant diseases. For these treatments to be effective, it is important to make sure that treatments are applied when the pathogens are vulnerable. If the UV light is provided before sporulation or after infection then it will be ineffective at providing protection. If applied during the germination of the spores, then UVC can be effective at preventing infection. Designing the light scheme to co-ordinate UVC application with spore release or germination may be an effective method for controlling disease in controlled environment chambers (Shin et al., 2008).

There are, however, health and safety issues regarding the use of UVC light in commercial settings where staff can be exposed.Just as different plant species have different light responses, the light responses of different pathogens vary, as do the interactions in different plant/pathogen systems in response to light. Schuerger and Brown (1997) observed that in tomatoes infected with bacterial wilt (Pseudomonas solanacearum) and cucumber plants infected with powdery mildew (Sphaerothecafuliginea), disease symptoms were at their lowest in plants grown under $100 \%$ red light. By contrast, for tomato mosaic virus (ToMV) on pepper plants, disease symptoms were slower to develop and less severe in plants grown in the presence of blue/UVA light. These data indicate that spectral modification could be used as part of an integrated disease management system, with the caveat that care must be paid to the development and achievement of appropriate light treatments (Johkan et al., 2010)

\section{Leds OfFer Disease Management Against Crop Loss}

Post-harvest spoilage of fruits or the protection of standing crops from the pathogen attack remains a challenge for agriculture scientists; nowadays, LEDs have been gaining attention as 
a handy tool for sustainable agricultural practices. For instance, single-spectral blue LEDs reduce the postharvest decay caused by Penicillium species in citrus fruits, when compared with dark conditions (Figure 1C; Table 1) (Liao et al, 2013 and Dsouza et.al,2015). Additionally, reduction in the infection of fruits has been observed due to the light-mediated stimulation of lipid signaling and subsequent accumulation of phospholipase A2, ethylene, and octanal (Alferez et.al, 2012) and (Ballester and Lafuente ,2017). Moreover, blue light can directly suppress the sporulation and germination of fungi (Table 1) (Suthaparan et.al, 2010 and Murdoch et al., 2013). Therefore, blue light-mediated post-harvest crop protection might be caused by a dual effect, resulting from the inhibition of fungal growth and stimulation of host defense responses.

LED generates the lightthrough an electro luminescent principle, which has several advantages. It is possible tospecify the desirable spectrum and they have long life. It has been found that UV radiationcan help to reduce powdery mildew infection in several plants (Willocquet et al. 1996).Similarly, it has been seen that filtration of far red light can reduce powdery mildew ingreenhouse crop. The powdery mildew lives outside of infected tissue where they are directlyexposed to the UV light. Powdery mildew has not any pigment that can protect from theradiation (Wilcox et al. 2008). UV-C has been used to reduce the grape wine powderymildew. Similarly UV-B was reported for controlling plant diseases. Increasing UV-B hasbeen found to reduce severity of powdery mildew in grapevine when plant canopies were manipulated to increase light penetration (Austin et al. 2011). Powdery mildew on tomato also depends on light intensity (Aguago et al.,2010). This is reported that lightintensity from 1000 lux to 5000 lux reduces conidial germination of O. neolycopersici. Thesame study also report tomato powdery mildew has optimal development at $25^{\circ} \mathrm{C}$ under atlight intensity 3500 lux and more than $90 \%$ conidia germinate and can be seen moderatedlobed appressoria (Kashimoto et al. 2003)

Various wavelengths have various effects on the germination of conidia(Austin et al. 2011). It is reported thatconidia germination reduce under red or blue light, while the highest conidial formation asrecorded in full spectrum white light (Purschwitz et al. 2008). Severity of powdery mildewwas highest in cucumber plants grown under white light (300-800 nm) compare to red light( Andrew and Brown, 1997). Reduced severity of cucumberpowdery mildew caused by P. fucusawas also observed under polythene films that block farred and UV light (Elad, 1997). However, cucumber powdery mildew caused by P. xanthiishowed highest number of powdery mildew under halide lamp, an intermediate number ofcolonies under red light or red to blue whereas lowest number colonies under red light(Schuerger, 1997). In addition far-red light inducedcucumber powdery mildew while red light reduced conidia formation and release. But it wasobserved that the far red followed by red light can neutralize the effect of red light onconidial release (Suthaparan et.al. 2010b). Powdery mildew in cucumber caused by P. xanthiiwas low in red, high in red to blue or red to far-red and highest under full spectrum( Christopher , 1997)

AS Ganesh, 2013 studied the treatment with night interruptionshowed germination of powdery mildew in both cases but the difference was not significant. So, dark period is necessary factor for the development of powdery mildew. Suthaparan et al. (2010a) also found more conidia production with exposure to darkness. However, the effect of light intensity of germination of powdery mildew is rarely reported. One of studies which report increasing light intensity prevents germination of powdery mildew in light with 1750 lux (Jacob et al. 2008). In the same study, the more conidia formation was observed at the $20^{\circ} \mathrm{C}$ and $70 \% \mathrm{RH}$ and higher light intensity at 5150 lux. Further he explains, low light intensity was associated with optimal germination of O. neolycopersici. However, Suthaparan et al. (2012) has reported the reduction rose of powdery by apply of UV -B with $0.1 \mathrm{Wm}$ 2 for 1 hours and null at $0.2 \mathrm{Wm}-2$ at low intensity. Amsalem et al. (2006) also found in the case of strawberry powdery mildew. Significant lower levels of disease severity are recorded at the highest light intensity of 7000 lux, compared to those at 1200 and 3800 lux, which are very similar and not significant in value One of the studies found that the germination of conidia in tomatopowdery mildew species is higher in dark filterwith comparison to combination of pink and green filter (Elad, Y1997). 
Review on Effect of Light on Disease Development and Management of Horticultural Crops Under Protected Cultivations

Table1. Induced disease resistance in crops treated with different light from LEDS

\begin{tabular}{|c|c|c|c|}
\hline LED Light & Light Intensity & Crops & Effect on Disease \\
\hline \multirow{7}{*}{ Red } & $261-550 \mu \mathrm{W} / \mathrm{cm}^{2}$ & Vicia faba & $\begin{array}{c}\text { Induces resistance against } B \text {. cinerea, } \\
\text { Altermaria tenuissima }\end{array}$ \\
\hline & $250-287 \mu \mathrm{W} / \mathrm{cm}^{2}$ & $\begin{array}{l}\text { Rice sl mutants cultivar } \\
\text { (Sekiguchi-asahi and } \\
\text { Sekiguchi-himenomochi) }\end{array}$ & $\begin{array}{l}\text { Induced resistance against } \\
\text { Magnaporthe grisea }\end{array}$ \\
\hline & $287 \mu W / \mathrm{cm}^{2}$ & Anabidopsis & $\begin{array}{c}\text { Induced resistance against } M \text {. jaranica, } \\
P \text {. syringae pv, tomato DC } 3000\end{array}$ \\
\hline & $287 \mu \mathrm{W} / \mathrm{cm}^{2}$ & $\begin{array}{l}\text { Piper nigrum, Cucurbita, } \\
\text { Solanum lycopersicum }\end{array}$ & Induced resistance against $P$. capsici \\
\hline & $\begin{array}{c}137 \mu W / \mathrm{cm}^{2} \\
350 \mu \mathrm{mol} \mathrm{m}\end{array}$ & Cucumis sativus & $\begin{array}{l}\text { Induced resistance against } C \text {. cassiicola } \\
\text { and } S \text {. fuliginet }\end{array}$ \\
\hline & $80 \mu \mathrm{mol} \mathrm{m} \mathrm{m}^{-2} \mathrm{~s}^{-1}$ & Vitis vinifent & Induced resistance against B. cincra \\
\hline & & Nicotiana benthamiana & $\begin{array}{l}\text { Induced resistance against } P \text {. syringac } \\
\text { pv. tabaci }\end{array}$ \\
\hline \multirow{5}{*}{ Blue } & $200 \mu \mathrm{mol} \mathrm{m}{ }^{-2} \mathrm{~s}^{-1}$ & Lactuca sation & $\begin{array}{c}\text { Induced resistance against grey mold } \\
\text { by } B \text {. cinereat }\end{array}$ \\
\hline & $50-150 \mu \mathrm{mol} \mathrm{m}^{-2} \mathrm{~s}^{-1}$ & Solanum lycopersicum & $\begin{array}{l}\text { Induced resistance against gray mold } \\
\text { disease by B. cinerna }\end{array}$ \\
\hline & $150 \mu \mathrm{mol} \mathrm{m}^{-2} \mathrm{~s}^{-1}$ & & $\begin{array}{l}\text { Suppression of sporulation of } \\
\text { A. cichori, P. pannosa }\end{array}$ \\
\hline & $3.4 \mu \mathrm{W} / \mathrm{cm}^{2}$ & & Reduced spore germination of $A$. niger \\
\hline & & Nicotiana benthamiana & $\begin{array}{l}\text { Induced resistance against } P \text {. syringae } \\
\text { pv. tabaci }\end{array}$ \\
\hline \multirow{2}{*}{ Green } & $80 \mu \mathrm{mol} \mathrm{m} \mathrm{m}^{-2} \mathrm{~s}^{-1}$ & Fnagaria $\times$ ananassa & Glomerella cingulate \\
\hline & & Cucumis sativus & C. orbiculare, B. cinerea \\
\hline
\end{tabular}

Source: Md. MohidulHasa et al., 2017,Korea Forest Research Institute, Molecules MDPI. Available on line

Specific wavelengths of light, especially red, blue and green LEDs, can induce disease resistance in standing crops against a wide range of phytopathogens (Figure 1C; Table 1) (Kim et al, 2013,Islam et al,.1998, Ahu et al., 2013,Kudo et al, al,.2011 and Raham et al.,2003]. Red light inhibits lesion development, induces expression of defense-related genes and also promotes synthesis of stilbenic compounds, when compared with such effects under white fluorescent light(Ahn et al., 2015). Stilbenes, also known as phytoalexins, play an important role in plant defense responses [Jeandet et al., 2002]. Moreover, increased synthesis of stilbenes, concomitant with the elevated expression of 16 defense-related genes, was observed after different wavelength exposure of plant products by LEDs [Ahn et al., 2015, and Ahu et al., 2013) furthermore, LEDs can also induce the expression of defense-related genes and subsequent ginsenosides biosynthesis in Ginseng plants [Ali et al., 2006)].

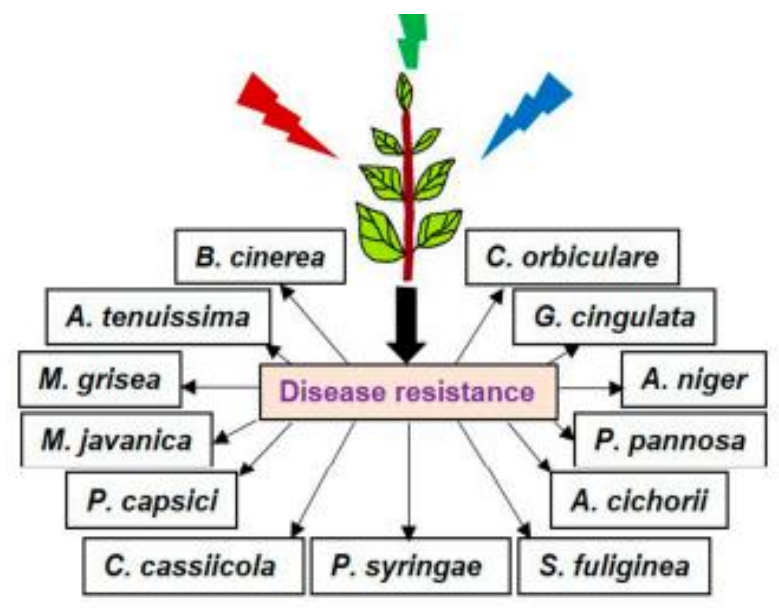

Figure1. Effect of LEDs on disease resistance against different pathogens

Source: Md. MohidulHasa et al., 2017, Korea Forest Research Institute, Molecules MDPI. Available on line 
Salicylic acid (SA) plays a vital role in plant disease resistance. The mutants of red: far-red light photoreceptors are known to be compromised in SA signaling stimulation and resistance to P. syringae (Genoud et al., 2002). Red LEDs induce SA content and expression of SAregulated PR-1 and WRKY genes in pathogen-inoculated cucumber plants (Wang et al,.2010). Taken together, it can be assumed that the red light-induced resistance may be closely associated with SA-mediated defense responses (Wang et al., 2010). Furthermore, the low red: far-red light ratio inhibits SA and jasmonic acid (JA)-mediated disease resistance in Arabidopsis by reducing the expression of SA- and JA-responsive genes. This result also shows the possible effect of LEDs on SA- and/or JA-mediated disease resistance (Dewit et al., 2013, Moreno et al., 2009). The plant defense response is quite complex-especially the crosstalk between SA an JA, and their roles against biotrophic and necrotrophic pathogens (Braidot et al., 2014). Generally, the defense response against biotrophic and necrotrophic pathogens is mediated by SA and JA, respectively. Different spectra of LEDs can activate different molecular events which can trigger accumulation of defense hormones (i.e., SA and JA). Therefore, a comparative investigation is required to unravel the molecular response in LED-treated plants during biotrophic and necrotrophic pathogen infection

\section{EFFECT OF Light DURATION ON DEVELOPMENT OF DISEASE}

Ganesh, 2013 studied growing inoculated and infected tomato plants in growth chambers in 16 hours red (LED)light seems to reduce powdery mildew in inoculated and null in noninoculated plants. This reduction can be seen in all part of the plants in term of multiple level, conidial germination and infection severity. 16 hours HPS light without night interruption significantly has more powdery mildew than 16 hours red (LED). This result suggests that powdery mildew is more sensitive to red light. There is clearly and significance difference of disease severity in the plant grown at 16 hours red (LED) light treatment without night interruption. One of the study conducted by Pettersen et al. (2010) reports that significant increase of rose powdery mildew under lighting 18 hours with 6 hours dark period with compare to continuous with HPS. Cole and Geerligs (1976) study reports that conidia developed faster in light than the dark period and released in the light period in tobacco powdery mildew. This result supported by Ganesh, 2013 of powdery mildew in tomato that HPS light has positive effect in development. It is clearly showed that the day length of 20 to 24 strongly suppressed the powdery mildew development in rose (Suthaparan et al. 2010a). In the same study, it is also found that the significance reduction of conidia when day length is increased from 18 to 24 hour

Table2. Effect of light quality and duration on disease severity as percentage in leaf area of non-inoculated tomato plants with 16 hours white (w) base light (16h). W (HPS) and $R$ (LED) with 2 hours night- interruption with 25 and $50 \mu$ mol $m$-2s-1 respectively

\begin{tabular}{|c|c|c|c|c|c|c|}
\hline $\begin{array}{l}\text { Days after } \\
\text { inoculation }\end{array}$ & $16 \mathrm{hw}$ & $\begin{array}{l}16 \mathrm{hw}+ \\
25 \mu \mathrm{mol} \\
\mathrm{m}-^{2} \mathrm{~s}-{ }^{1} \mathrm{~W}\end{array}$ & $\begin{array}{l}16 \mathrm{hw}+ \\
50 \mu \mathrm{mol} \\
\mathrm{m}^{2} \mathrm{~s}-{ }^{-1} \mathrm{~W}\end{array}$ & $16 \mathrm{hR}$ & $\begin{array}{l}16 \mathrm{hw}+ \\
25 \mu \mathrm{mol} \\
\mathrm{m}-{ }^{2} \mathrm{~s}-{ }^{\mathrm{I}} \mathrm{R}\end{array}$ & $\begin{array}{l}16 \mathrm{hw}+ \\
50 \mu \mathrm{mol} \\
\mathrm{m}^{2} \mathrm{~s}^{-1} \mathrm{R}\end{array}$ \\
\hline 9 & $0.3 \pm 0.1$ & $0.12 \pm 0.1$ & $0.08 \pm 0.1$ & $0 \pm 0$ & $0.1 \pm 0.1$ & $0.2 \pm 0.1$ \\
\hline 12 & $0.3 \pm 0.2$ & $0.3 \pm 0.2$ & $0.1 \pm 0.1$ & $0 \pm 0$ & $0.3 \pm 0.2$ & $0.3 \pm 0.2$ \\
\hline 15 & $1.6 \pm 0.3$ & $1.1 \pm 0.2$ & $1.2 \pm 0.2$ & $0 \pm 0$ & $0.9 \pm 0.3$ & $0.8 \pm 0.3$ \\
\hline 18 & $12.3 \pm 2.3$ & $11.7 \pm 2.2$ & $13.2 \pm 2.4$ & $0 \pm 0$ & $10.12 \pm 2.3$ & $11.3 \pm 2.7$ \\
\hline
\end{tabular}

Source: Ganesh Kumar Upadhyaya, 2013 Norwegian University of Life Sciences.Avalable on line

The role of light in different stage of the conidia production has varied from species to species (Carver \& Carr 1978). In the same study, he explain, some grower provides continuous light to increase yield as well as to maintain the heat in greenhouse without night interruption, in such condition they find that fewer mildew in rose plants. The powdery mildew in barely is independent of light can develop continuously in light, dark and shade (Pady et al. 1969). However, the conidia formation is totally dependent in light in case of Erysiphe polygon (Pady et al. 1969 


\section{SPECTRAL QuAlity AFFECTS DiSEASE DEVELOPMENT}

Light plays important role on fungal development. It has been found that the powdery mildew on the Strawberry leaves are not affected by light (Peries 1962) and another study on powdery mildew has found that powdery mildew grow completely in the darkness. It has been found that conidia formation rose powdery mildew is independent; however, maximum growth occurs during dark periods and maturation and release occurs only in day time (Frinking 1977). It is reported that the increase in the length of day from to $20-24$ by using supplementary light reduces significantly sporulation of p. pannosaand severity of powdery mildew in greenhouse roses (Suthaparan et al. 2010a). Some growers supply continuous light to cut rose in order to increase yields, but also maintaining minimum heat on greenhouse by the help of heat producing lamp. This help to reduce powdery mildew in rose with comparison to switch off light to make dark condition (Carver \& Carr 2008). UV radiation is known to suppress or kill a variety of fungi. Powdery mildew may be suppressed with relatively short exposure to low intensity UV-B (Ganesh , 2013)

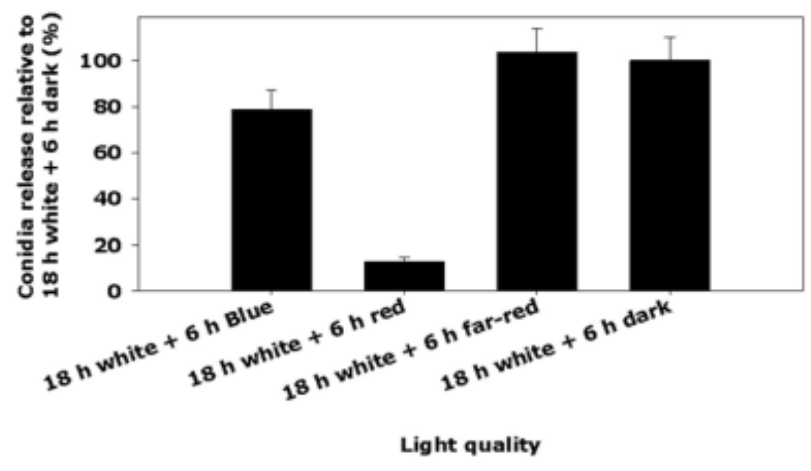

Figure2. The effect of different combination of HPS and red (LED) light on germination, infection and development of success colony of o. neolycopersiciat three days after inoculation

Source: Ganesh Kumar Upadhyaya, 2013 Norwegian University of Life Sciences. Avalable on line

Several types of plant irradiation source have been proposed for use in spaced based control ecological life support system/CESS/ (Bartel et.al.1992); Sager and Wheeler, 1992). Light emitting diodes (LEDS) have advantages of low mass and volume solid state construction, long life and reduced heat out compared to high intensity discharges lamps(Bartel et al.1992;Brown et.al,1995; Bala et. al, 1991). Futther more, soild state diode emitting light of specific and restricted wavelength might be used in lighting arrays that would permit the independent selection of different intensities or red, blue and far-red wavelengths for optimum production of diverse plant species. Plant in CELSS moduels will be colonized by a diversity of microorganisms, some of which may cause plant health problems (Gonzales et.al, 1996). LED arrays of unique spectral output that might inhibit the development of specific plant disease would be extremely useful in CELSS integrate pest management programs. For example, spectral quality can have significant effect on plant physiology (Smith, 1982) that could alter plant resistance to microbial challenge. Furthermore, many fungal (Vakalounkis, 1982), bacterial (Guo et.al. 1983) and Viral (Thomas te al.1998) disease of plants are affected by the spectral quality of the primary light source. Foliar fungal diseases of various crops have been suppressed in green house when UV-A (320-400nm) absorbing viny films were used to cover the structures (Honda and Nemoto, 1985). The apparent mechanism in disease control was the suppression of spore germination and sporulation of the fungal pathogen caused by extermly low levels of blue or UV-A light (Vakalounakis and Christias, 1981)

\subsection{Inoculated Plants}

As research done by Andrew, 1997 disease in the Tomato Mosaic Viruses (TOMV) pepper pathosystem was characterized by systemic mottling, leaf chlorosis, petiole and stem necrosis, and plant wilt. Disease systemwere most severe on inoculated plants grown under the 660 or 660/735 LEDS array (Table2). Disease system were lowest for inoculated plants grown under the MH lamp. However, leaf chlorosis and system mottling caused by TOMV were first observed between 4 and 5 days on all incoculated plant grown under the LED arrays or MH lamp. 


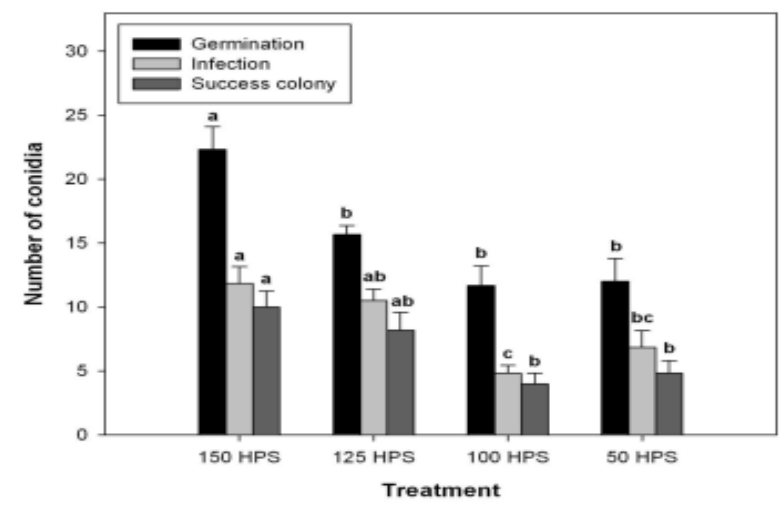

Figure3. The effect of different combination of HPS and red (LED) light on germination, infection and development of success colony of o. neolycopersiciat three days after inoculation

Table2. Effects of spectral quality on the development of tomato mosaic virus (TOMV) in pepper

\begin{tabular}{|c|c|c|c|c|}
\hline \multirow[b]{2}{*}{ Growth characteristic } & \multicolumn{4}{|c|}{ Spectral array ${ }^{x}$} \\
\hline & MH & $660 / \mathrm{BF}$ & 660 & $660 / 735$ \\
\hline \multicolumn{5}{|l|}{ Plant fresh mass (g) } \\
\hline Control $^{y}$ & $43.7 \mathrm{aA}$ & $35.7 \mathrm{bA}$ & $28.3 \mathrm{cA}$ & $30.3 \mathrm{cA}$ \\
\hline Inoculated ${ }^{y}$ & $15.7 \mathrm{aB}$ & $11.5 \mathrm{bB}$ & $7.2 \mathrm{cB}$ & $7.3 \mathrm{cB}$ \\
\hline $\begin{array}{l}\text { Inoculated as a percentage } \\
\text { of control } \\
\end{array}$ & $\begin{array}{l}37 \text { a } \\
54\end{array}$ & $\begin{array}{l}32 a b \\
79\end{array}$ & $26 \mathrm{bc}$ & $\begin{array}{l}24 \mathrm{c} \\
100\end{array}$ \\
\hline
\end{tabular}

${ }^{2} \mathrm{MH}=$ metal halide lamp; BF = blue fluorescent lamps; 660 = red LEDs; 735 = far-red LEDs.

Source: Andrew C.S., 1997.Hort sciencice 32(1):96-100, Avaliable on line

As research done by (Anderw, 1997) fresh mass of inoculated plant grown under the 660/BF light source was significantly lower than for the $\mathrm{MH}$ grown plant and significantly higher than for the 660 or the 660/735 grown plant. However, when disease severity was calculated as the percentage of reduction in plant fresh mass of inoculated compared to non inoculated plants, $\mathrm{MH}$ and 660BF grown plant were similar (Deng, 1999). All pepper plants inoculated with TOMV and grown under the 660 or 660/735 LED arrays wilted between 6 and 7 day after plantation. Plant wilt in pepper grown under the 660 or the 660/735 LED arrays was associated with a severe and rapid collapse of the main stem between second and forth internodes (Griebel and Zeier, 2008)

Foliar colonies of S.fuliginea on cucumber under all light sources were firist 7 days after inoculation (Islam et al., 2002). The distribution of powdery mildew colonies on inoculated leaves was generally random and there was no indication that distance from light source or plant canopy structure had any effects on colony count or diameter. The number of powdery mildew colons per leaf was highest under $\mathrm{MH}$, intermidate under 66o/BF or 660/735 LED and Lowest under 660LEDS (Rahman et al., 2010)

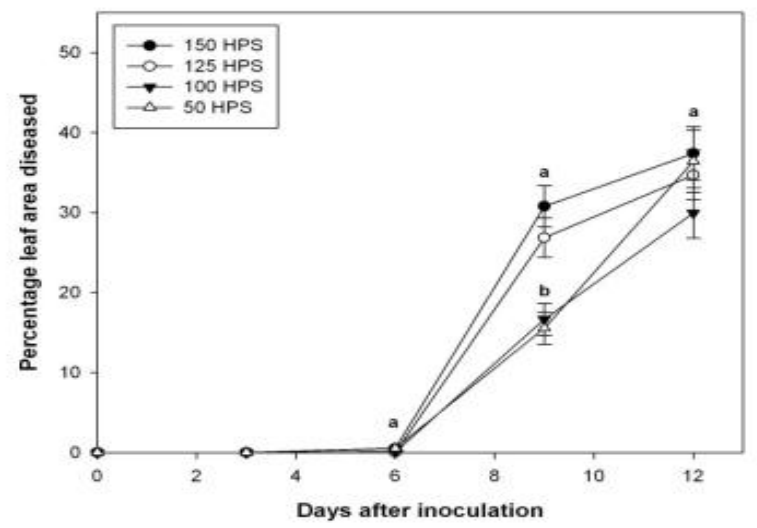

Figure4. Effect of different combination of HPS and red LED light on severity of powdery mildew in tomato $\mathrm{cv}$. Espero; inoculated by spraying $20 \mathrm{ml}$ spore suspension per plan 
Review on Effect of Light on Disease Development and Management of Horticultural Crops Under Protected Cultivations

Table3. Effect of spectral quality on the development of Sphaerothecafulignea on cucumbers

\begin{tabular}{lcccc}
\hline \hline & \multicolumn{4}{c}{ Spectral array } \\
\cline { 2 - 5 } Growth characteristics & $\mathrm{MH}$ & $660 / \mathrm{BF}$ & 660 & $660 / 735$ \\
\hline Fresh mass (g), noninoculated & & & & \\
$\quad$ control plants & $90 \mathrm{a}^{y}$ & $41 \mathrm{bc}$ & $34 \mathrm{c}$ & $65 \mathrm{~b}$ \\
Colonies/leaf & $121 \mathrm{a}$ & $56 \mathrm{~b}$ & $20 \mathrm{c}$ & $43 \mathrm{~b}$ \\
Colony diameter (mm) & $5.4 \mathrm{a}$ & $3.9 \mathrm{~b}$ & $3.4 \mathrm{~b}$ & $3.5 \mathrm{~b}$ \\
\hline
\end{tabular}

${ }^{2} \mathrm{MH}=$ metal halide lamp; BF = blue fluorescent lamps; 660 = red LEDs; 735 = far-red LEDs.

Source: Rahman et al., 2010Journal of Psychopathology. Phytopathol. Z. 2003, Furthermore, Imade et al., 2014 studied microscopic observation of powdery mildew colonis on LED grown plant indicated that conidiation was dramatically inhibited on leaves grown under the 660 LED array and slightly supperesed on leaves grown under 660BF or 660/735 LED arrays as compared to MH grown plant

As Islam et al., 2008 stated the effect of spectral quality on the development of P.solanacearumin tomato. Plant fresh mass between inoculated and non-inoculated tomatoes differed significantly with MH-660/BF and 660/735 grown plant but not with 660grown plant .plant height inoculated and non inoculated differed significantly with 660BF grown plant (D'Souz et al., 2015). The percentage of plant welting at the end of each trial was highest for the $\mathrm{MH}$ grown plants intermidate for $660 \mathrm{~B} / \mathrm{F}$ of 660/735 grown plant and zero for for the 660 growing plant. Disease symptom caused lowest in 660 grown plant and variable in plants grown under the other light source.

Table4. Effect of spectral quality on the development of Pseudomonas Solanacearum on tomatoes

\begin{tabular}{|c|c|c|c|c|c|c|c|c|}
\hline \multirow{3}{*}{$\begin{array}{l}\text { Growth } \\
\text { characteristic }\end{array}$} & \multicolumn{8}{|c|}{ Spectral array ${ }^{2}$} \\
\hline & \multicolumn{2}{|c|}{ MH } & \multicolumn{2}{|c|}{$660 / \mathrm{BF}$} & \multicolumn{2}{|c|}{660} & \multicolumn{2}{|c|}{$660 / 735$} \\
\hline & $\mathrm{CON}^{y}$ & INOC & $\mathrm{CON}$ & INOC & $\mathrm{CON}$ & INOC & $\mathrm{CON}$ & INOC \\
\hline \multicolumn{9}{|l|}{$\overline{\text { Plants }}$} \\
\hline Fresh $\mathrm{n}$ & $32.0 \mathrm{a}^{x}$ & $19.2 \mathrm{~d}$ & $28.1 \mathrm{ab}$ & $19.7 \mathrm{~d}$ & $24.6 \mathrm{bc}$ & $23.4 \mathrm{c}$ & $28.2 \mathrm{a}$ & $22.4 \mathrm{~cd}$ \\
\hline Height ( & $14.2 \mathrm{~b}$ & $12.1 \mathrm{~b}$ & $19.2 \mathrm{a}$ & $16.1 \mathrm{~b}$ & $20.1 \mathrm{a}$ & $18.8 \mathrm{a}$ & $18.7 \mathrm{a}$ & $18.2 \mathrm{a}$ \\
\hline Wilted $(\%)^{*}$ & -.. & 78 & ... & 22 & $\ldots$ & 0 & $\ldots$ & 33 \\
\hline Lesion length $(\mathrm{cm})^{v}$ & --- & $3.1 \mathrm{a}$ & -- & $3.5 \mathrm{a}$ & -- & $3.1 \mathrm{a}$ & -- & $3.5 \mathrm{a}$ \\
\hline
\end{tabular}

${ }^{2} \mathrm{MH}=$ metal halide lamp; BF = blue fluorescent lamps; 660 = red LEDs; 735 = far-red LEDs.

${ }^{y} \mathrm{CON}=$ noninoculated control nlants: INOC $=$ inoculated nlants.

Source: D' souse et al., 2015Comprehensive. Rev. Food Sci. Food Saf. 2015.Avaliable on line

Spectral quality can have a profound effects on plant growth and physiology (Sage, 1992; Sengar, 1982; Smith, 1982) and inhibits diseases development in several host pathogen system.In the TOMV/pepper pathosystem plant disease symptoms were least in plant grown under light source that contained blue and UV-A irradiation (MH lamps and 660BF LED arrays) and worest in plant grown under light source that lacks bule and UV-A irradiation (660 and 660/735 LED arrays.

Disease development in the S.fuliginea/cumber pathosystem was worst on leaves grown under the MH lamps (highest amount of bule and UV-A irradiation) and least on leaves grown under the 660LED array (no blue or UV-A irradiation). Most characteristics used to measure the effects of spectral quality on diseases development indicated that tomato plant grown under red light $(660 \mathrm{~nm})$ were the most resistance to P.Solonacearum, even though the size shape of the internal necrotic stem lesion all four light source (Anderw, 1997). This result is supporeted by Gue et.al.1993;Smith and Kennedy 1970) that bactrieal disease of plant can be affected by shifts in spectral quality.

Thestudy conducted by Suthaparan (2010) documents that the 18 hours full spectrum white lightfollowed by low intensity red light significantly reduced the conidia formation and release ofrose powdery mildew. In the same study, he found that the red light strongly reducedpowdery mildew and reduced formation of conidia in P. pannosain green house rose production compared to the white light. The research done by Ganesh,2013 on (LED) shows the significancereduction of powdery mildew development as well as transmitted disease. This also reported by Wang and Hong et al. (2010) in cucumber powdery mildew which is reduced significantly under the red light treatment $(628.6 \mathrm{~nm})$ compared to purple, blue green yellow and broad spectrum white .The report published by Schuerger, Andrew C and Brown, Christopher S (1997) also reports that least rose powdery mildew 
on the red light treatment. But the study on the rose, the blue light has significant effect on the reduction of germination of conidia with comparison to red, far- red and white light. The germination of conidia is not reduced by red or far red in case Podosphaerapannosawith compared to white light (Suthaparan et al. 2010b)

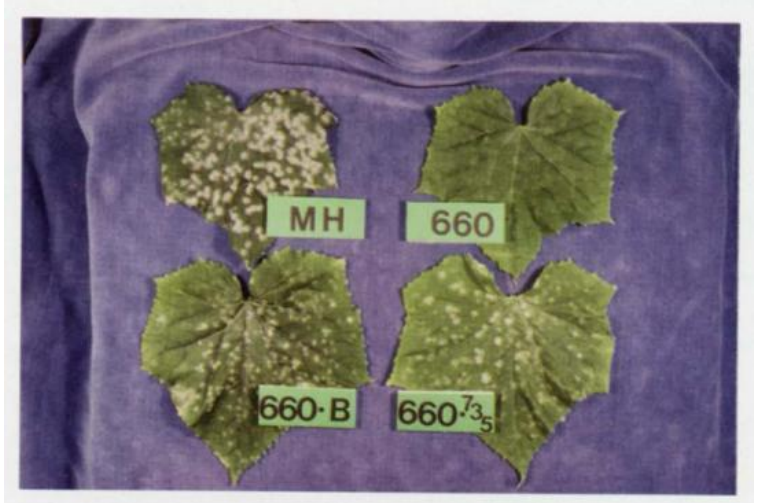

Fig2. Cucumber leaves inoculated with Sphaerothecafuliginea grown under a metal halide (MH) lamp or under red (660), red+bule (660B) or red +far red (660-735) light emitting diode (LED) arrays. Number and diameters of colonies of S.fuliginea were highest on cucumber leaves grown under the MH lamp and lowest on cucumber leaves grown under the 660 LED array.

Source: Wanga et al., 2010 European journal plant pathology, available on line

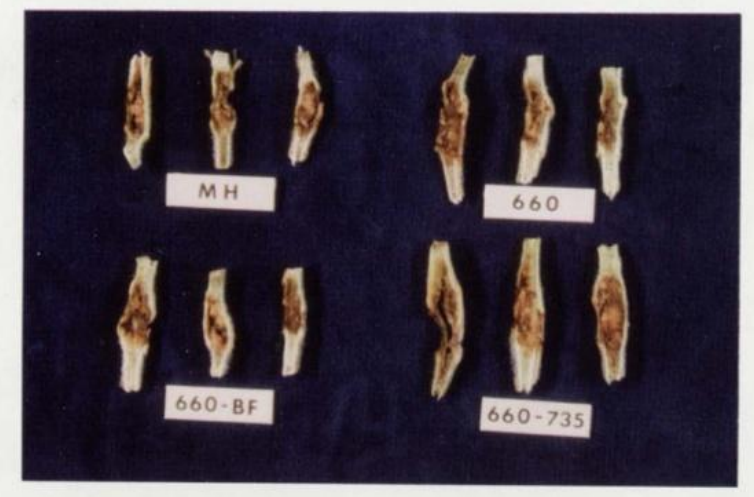

Fig3. Longitudnal stem section of tomato inoculated with Pseudomonas solanacearum and grown under metal halide $(\mathrm{MH})$ lamp,red (660), red +bule (660B) or red +far red (660-735) light emitting diode (LED) arrays.Necrotic stem lesion caused by P.solanacearum were similar in size and severity in inoculated plant grown under the MH lamp or LED arrays, necrotic stem lesions were absent in control plants inoculated with sterile deionized water.

Source: Kudo et al., 2011, ActaHortic. Available on line.

\section{SUMMERY}

The ultimate goal of crop production is to obtain better nutritional quality along with high yield. Because of environmental constraints and a reduction in the availability of cultivated lands, there is an urgent need to develop indoor cultivation systems in order to obtain yield parameters that are similar to or higher than outdoor cultivation systems. For this purpose light -induced plant disease resistance could suggest new approaches towards minimizing the use of chemicals for crop protection. Advances in technology are rapidly exploited by the protected horticulture industry light act us disease development and management. Light affects many aspects of plant biology and many of these responses influence plant resistance to disease. Low red: far-red ratios decrease the production of many secondary metabolites involved in disease resistance. The spores of many plant pathogens are killed by exposure to solar radiation. The different plant species have different light responses; the light responses of different pathogens vary, as do the interactions in different plant/pathogen systems in response to light. Specific wavelengths of light, especially red, blue and green can induce disease resistance in standing crops against a wide range of phyto pathogens. Spectral quality can have significant effect on plant 
physiology that could alter plant resistance to microbial challenge. Furthermore, many fungal, bacterial and viral diseases of plants are affected by the spectral quality of the primary light source. Foliar fungal diseases of various crops have been suppressed in green house when UV-A (320-400nm) absorbing viny films were used to cover the structures. The apparent mechanism in disease control was the suppression of spore germination and sporulation of the fungal pathogen caused by extremely low levels of blue or UV-A light. Interestingly, red, blue, and green can induce systemic acquired resistance in various plant species against fungal pathogens under green house condition. One of the major limitations of this technology, for its effective use under in vitro conditions, lies in its low penetrance. Additionally, optimal spectral conditions are not precisely known for number of crops. But, finally we can summarized the light can be useful as a component of an integrated disease management program source in green house conditions.

\section{REFERENCES}

[1] Ahn, S.Y.,Kim, S.A., Baek, K.H., Yun, H.K. 2013.Inhibiting wildfire and inducing defense-related gene expression by led treatment on Nicotianabenthamiana. J.Plant Pathol. 2013,95, 477-483

[2] Ahn, S.Y., Kim, S.A., Yun, H.K. 2015. Inhibition of Botrytis cinerea and accumulation of stilbene compounds by light-emitting diodes of grapevine leaves and differential expression of defense-related genes. Eur. J. Plant Pathol. 2015, 143, 753-765

[3] Aguayo, E., Escalona, V. \&Artés, F. 2004.Quality of fresh-cut tomato as affected by type of cut, packaging, temperature and storage time. European Food Research and Technology, 219 (5): 492-499

[4] Alferez, F., Liao, H.L., Burns, J.K. 2012. Blue light alters infection by Penicilliumdigitatum in tangerines. Postharvest Biol. Technol. 2012, 63, 11-15. [CrossRef]

[5] Ali, M.B., Hahn, Yu, K.W., Paek,, E.J. K.Y. 2006. Methyl jasmonate and salicylic acid elicitation induces ginsenosides accumulation, enzymatic and non-enzymatic antioxidant in suspension culture Panax ginseng roots in bioreactors. Plant Cell Rep. 2006, 25, 613-620

[6] Amsalem, L., Freeman, S., Rav-David, D., Nitzani, Y., Sztejnberg, A., Pertot, I. \&Elad, Y. 2006. Effect of climatic factors on powdery mildew caused by sphaerotheca macularis f. sp. Fragariae on strawberry. European journal of plant pathology, 114 (3): 283-29

[7] Austin, C. N., Grove, G. G., Meyers, J. M. \& Wilcox, W. F.2011. Powdery mildew severity as a function of canopy density: Associated impacts on sunlight penetration and spray coverage. American Journal of Enology and Viticulture, 62 (1): 23-31.

[8] Andrew. C.S.1997. Spectral quality affect disease development of Three pathogen on Hydroponically growth plants. Avaliable on line Hort SC 32/1/:96-100

[9] Ballaré. C. L., Mazza.C. A., Austin.A. T., and Pierik.R. 2012. Canopy light and plant health. Plant Physiol. 160:145-155.

[10] Ballester, A.R., Lafuente, M.T .2017. LED Blue Light-induced changes in phenolics and ethylene in citrus fruit: Implication in elicited resistance against Penicilliumdigitatum infection. Food Chem. 2017, 218, 575-583. [CrossRef] [PubMed]

[11] Barta,D.J.Tibbits,T.W.BulaR.J.,and Morrow,R.C.1992. Evaluation of light emitting diode characteristics for space based plant irradiation source. Adv,space Res 121, 141-149

[12] Braidot, E.Petrussa, E.Peresson, C. Patui, S.Bertolini, A. Tubaro, F. Wahlby, U. Coan, M. Vianello, A.Zancani, M.2014. Low-intensity light cycles improve the quality of lamb's lettuce (Valerianellaolitoria[L.] Pollich)during storage at low temperature.Postharvest Biol. Technol. 2014, 90, 15-3

[13] Brown,C.S. and Schuerger,A.C.1993.Growth of pepper,cucumber and lettuce under light emitting diodes,plant physiol,102:88

[14] Bula, R.J Morrow.R. C., T.W.Tibbites, D.J. Barta, R.W. Ignatius,and T.S. Martin, 1991. Light emiting diodes as a radiation source for plants. Hort science 26:203-205

[15] Cole, J. \& Geerligs, J. 1976. Time-lapse photography of formation and release of conidia of < i > Erysiphe cichoracearum </i > on tobacco. Transactions of the British Mycological Society, 67 (2): 339-342

[16] Corrochano, L. M. 2007. Fungal photoreceptors: sensory molecules for fungal development ad behavior. Photochem.Photobiol. Sci. 6:725-736.

[17] Carver, T. \& Carr, A. 2008. The early stages of mildew colony development on susceptible oats.Annals of Applied Biology, 89 (2): 201-209

[18] D'Souza, C. Yuk, H.G. Khoo, G.H. Zhou, W. 2015. Application of light-emitting diodes in food production, postharvest preservation, and microbiological food safety. Compr.Rev. Food Sci. Food Saf. $2015,14,719-740$. 
[19] Davis, P. A. 2013. Securing skills and expertise in crop light responses for UK protected horticulture, with specifc reference to exploitation of LED technology. AHBD Project CP085 Annual Report 2013.

[20] De Wit, M. Spoel, S.H. Sanchez-Perez, G.F. Gommers, C.M.M. Pieterse, C.M.J. Voesenek, L.A.C.J.Pierik, R.2013. Perception of low red: Far-red ratio compromises both salicylic acid- and jasmonic acid-dependent pathogen defences in Arabidopsis. Plant J. 2013, 75, 90-103

[21] Elad, Y. 1997. Effect of filtration of solar light on the production of conidia by field isolates of Botrytis cinerea and on several diseases of greenhouse-grown vegetables. Crop Protection, 16 (7): 635642.

[22] Frinking, H. 1977. Research on wind dispersion of rose-mildew spores (Sphaerotheca pannosa) in field, glasshouse and climate room.Grava, 16: 155-158.

[23] Deng, X.W .and Quail, P.H. 1999.Signalling in light-controlled development. Semin. Cell Dev. Biol. 1999, 10, 121-129. [CrossRef] [PubMed]

[24] Genoud, T. Buchala, A.J. Chua, N.H. Metraux, J.P. 2002. Phytochromesignalling modulates the SAperceptive pathway in Arabidopsis. Plant J. 2002, 31, 87-95

[25] Gonzales, A.A. SchuergerA.C.BarfordC.and Mitchell R.1996.Engineringstrategs for the design of plant nutrient deliver system for use in space; Approaches to countering microbiological contamination.adv.space Res. 18

[26] Griebel, T. and ZeierJ. 2008. Light regulation and daytime dependency of inducible plant defenses in Arabidopsis: phytochrome signaling controls systemic acquired resistance rather than local defense. Plant Physiol. 147:790-801

[27] Guo,A.Reimers,P.J. and Leach,J.E.1993. Effect of light on incompatible interaction between xanthomonasoryzaepv.oryzae and rice physiolmol. Planypathol 42:413-425

[28] Ganesh, K. U. 2013.Effect of light on powdery mildew in greenhouse tomato (solanumlycopersicum 'espero'). Department of Plant and Environmental Sciences (IPM)Norwegian University of Life Sciences. MSc Thesis

[29] Honda, Y. and NemotoM. 1985. Control of Gray mold of green house cucumber and tomato by inhibiting sporulation Plant Dis.Rptr 61:1041-1044

[30] Imada, K. Tanaka, S. Ibaraki, Y. Yoshimura, K. Ito, S.2014.Antifungal effect of 405-nm light on Botrytis cinerea.Lett. Appl. Microbiol. 2014, 59, 670-676

[31] Islam, S. Z.Honda, Y. and Arase S. 1998.Light-induced resistance of broad bean against Botrytis cinerea. J. Phytopathol. 146:479-485.

[32] Islam, S.Z. Honda, Y. Arase, S. 1998. Light-induced resistance of broad bean against Botrytis cinerea. J. Phytopathol. 1998, 146, 479-485

[33] Jacob, D., David, D. R., Sztjenberg, A. \& Elad, Y. 2008.Conditions for development of powdery mildew of tomato caused by Oidium neolycopersici. Phytopathology, 98 (3): 270-281

[34] Jeandet, P. Douillt-Breuil, A.C. Bessis, R. Debord, S. Sbaghi, M. Adrian, M. 2002. Phytoalexins from the vitaceae: Biosynthesis, phytoalexin gene expression in transgenic plants, antifungal activity, and metabolism. J. Agric. Food Chem. 2002, 50, 2731-2741

[35] Johkan, M. Shoji, K.Goto, F. Hashida, S. Yoshihara, T.2010. Blue light-emitting diode light irradiation ofseedlings improves seedling quality and growth after transplanting in red leaf lettuce. Hortscience 2010, 45,1809-181

[36] Kanetis, L. G. Holmes,J. and OjiamboP. S. 2010. Survival of Pseudoperonospora cubensis sporangia exposed to solar radiation. Plant.Pathol. 59:313-323

[37] Kashimoto, K., Matsuda, Y., Matsutani, K., Sameshima, T., Kakutani, K., Nonomura, T., Okada, K., Kusakari, S., Nakata, K. \& Takamatsu, S. 2003. Morphological and molecular characterization for a Japanese isolate of tomato powdery mildew Oidium neolycopersici and its host range. Journal of General Plant Pathology, 69 (3): 176-185

[38] Kim, K. Kook, H.S. Jang, Y.-J.Lee, W.H. Kamala-Kannan, S., Chae, J.-C. Lee, K.J .2013. The effect of blue-light emitting diodes on antioxidant properties and resistance to Botrytis cinerea in tomato. J. Plant Pathol. Microbiol.2013, 4, 203

[39] Kozai, T. 2013. Sustainable plant factory: closed plant production systems withartifcial light for high resource use effciencies and quality produce. ActaHortic. 1004:27-40

[40] Kudo, R. Ishida, Y. Yamamoto, K.2011. Effects of green light irradiation on induction of disease resistance in plants.ActaHortic. 2011, 907, 251-254

[41] Lekkham, P. Srilaong, V. Pongprasert, N. Kondo, S.2016. Anthocyanin concentration and antioxidant activity inlight-emitting diode (LED)-treated apples in a greenhouse environmental control system. Fruits 2016, 71,269-274 
[42] Liao, H.L. Alferez, F. Burns, J.K, 2013. Assessment of blue light treatments on citrus postharvest diseases. Postharvest Biol. Technol. 2013, 81, 81-88. [CrossRef]

[43] Liu, Y. and Bell-Pedersen,D. 2006.Circadian Rhythms in Neurosporacrassa and Other Filamentous Fungi.Eukaryot. Cell 5:1184-1193

[44] MohidulHasan,M.D.Tufail, B.RiteshGhosh,I.D .Sun. K. L. and Hanhong B. 2017. An Overview of LEDs' Effects on the Production of Bioactive Compounds and Crop Quality. Division of Forest Insect Pest and Diseases, Korea Forest Research Institute, Seoul 02455, Korea.

[45] Moreno, J.E. Tao, Y. Chory, J.Ballare, C.L.2009. Ecological modulation of plant defense via phytochrome control of jasmonate sensitivity. Proc. Natl. Acad. Sci. USA 2009, 106, 4935-4940

[46] Murdoch, L.E. Mckenzie, K. Maclean, M. Macgregor, S.J. Anderson, J.G. 2013. Lethal effects of highintensity violet 405-nm light on Saccharomyces cerevisiae, Candida albicans, and on dormant and germinating spores of Aspergillusniger. Fungal Biol. 2013, 117, 519-527

[47] Pady, S., Kramer, C. \& Clary, R. (1969). Sporulation in some species of Erysiphe. Phytopathology, 59: 844-848.

[48] Pearson, S.Davis,P. A. and Kitchener H. 2015.Commercial review of lighting systems for UK Horticulture. AHDB Horticulture CP 139 Final Report

[49] Pettersen, R. I., Torre, S. \& Gislerød, H. R. 2010.Effects of intracanopy lighting on photosynthetic characteristics in cucumber. Scientia horticulturae, 125 (2): 77-81

[50] Peries, O. 1962.Studies on strawberry mildew, caused by Sphaerothecamacularis (Wallr. ex Fries) Jaczewski*. Annals of Applied Biology, 50 (2): 211-224.

[51] Purschwitz, J., Müller, S., Kastner, C., Schöser, M., Haas, H., Espeso, E. A., Atoui, A., Calvo, A. M. \& Fischer, R. 2008. Functional and Physical Interaction of Blue-and Red-Light Sensors in $<\mathrm{i}>$ Aspergillusnidulans $</ \mathrm{i}>$.Current Biology, 18 (4): 255-25

[52] Quail, P.H. Boylan, M.T. Parks, B.M. Short, T.W. Xu, Y. Wagner, D. 1995. Phytochromes: Photo sensory perception and signal transduction. Science 1995, 268, 675-680. [CrossRef] [Pub Med]

[53] Rahman, M.Z. Honda, Y. Arase, S. 2003. Red-light-induced resistance in broad bean (Viciafaba L.) to leaf spot disease caused by Alternariatenuissima. J. Phytopathol. Phytopathol. Z. 2003, 151, 86-91

[54] Sager, J.C. and Wheeler.R.M.1992. Application of sunlight and lamps for plant irradiation in space bases, Adv. space Res, 12:133-140

[55] Sager, L.C.1992.Shade avoidance, P.371-395> In L.C. stage (ed.). Pigment of the imagination. Academic London.

[56] Schuerger, A. C. and Brown,C. S. 1997. Spectral quality affects disease development of three pathogens on hydroponically grown plants. HortScience 32:96-100

[57] Senger, H.1982. The effect of bule light on plant and microorganisms. Photochem photobiol.35:911-920

[58] Simith, M.A. and Kennedy, B.W.1970. Effects of light on reaction of soyabean to Pseudomansglycinea .phytopathology 60: 723-725

[59] Shin, K.S. Murthy, H.N. Heo, J.W. Hahn, E.J.Paek, K.Y.2008. The effect of light quality on the growth and development of in vitro cultured Doritaenopsisplants. Acta Physiol. Plant.2008, 30, 339-34

[60] Shibuya, T., Itagaki, K., Tojo, M., Endo, R. \&Kitaya, Y. 2011. Fluorescent illumination with high red-tofar-red ratio improves resistance of cucumber seedlings to powdery mildew. HortScience, 46: 429-431.

[61] Smith, H.1992. Light quality photoreception and plant strategic. Ann.Rev. plant physiol.33:4810518

[62] Suthaparan, A., Stensvand, A., Torre, S., Herrero, M., L., Pettersen, R. I., Gadoury, D. M. \& Gislerød, H. R. 2010a. Continuous lighting reduces conidial production and germ inability in the rose powdery mildew pathosystem. Plant Dis., 94: 339-344

[63] Suthaparan, A. S. Torre, A. Stensvand, M. L. Herrero, R. I. Pettersen, D. GadouryM. 2010b. Specifc Light emitting diodes can suppress sporulation of Podosphaerapannosa on greenhouse roses. Plant Dis. 94:1105-1110

[64] Suthaparan, A., Stensvand, A., Solhaug, K., Torre, S., Mortensen, L., Gadoury, D., Seem, R. \&Gislerød, H. 2012. Suppression of Powdery Mildew (Podosphaerapannosa) in Greenhouse Roses by Brief Exposure to Supplemental UV-B Radiation. Plant Disease, 96 (11): 1653-166

[65] Thomas, P.E.Hassan S. and mink G.I. 1998. Influence of light quality on translocation of tomato Yellow top Viruse and potato leaf roll virus in Lycopersicon peruvianum and some of its tomato hybrids ,phytopathology 78:1160-1164

[66] Vakalounakis, D.J.1992. Control of fungia diseases of greenhouse tomato under long wave infrared ansorbing plastic film. Plant Dis.76:43-46

[67] Vakalounakis, D.J. and ChristiasC.1981. Sporulation in Alternaria Cichorii is control by a blue and near ultraviolet reversible photoreaction.can.J.bot.59;626-628 
[68] Wang, H. Jiang, Y.P. Yu, H.J. Xia, X.J. Shi, K. Zhou, Y.H.Yu, J.Q. 2010. Light quality affects incidence of powdery mildew, expression of defence-related genes and associated metabolism in cucumber plants. Eur. J. Plant Pathol. 2010, 127, 125-135

[69] Wilcox, W. F., Gadoury, D. M., Seem, R. C., Lakso, A., Austin, C. N., Wicks, T., McCarthy. \& Magarey, P. 2008. Effects of Sunlight Exposure on the Development and Management of Powdery Mildew. Report of... proposals received and awards made,and Final reports for grant year: 225.

[70] Willocquet, L., Colombet, D., Rougier, M., Fargues, J. \& Clerjeau, M. 1996.Effects ofradiation, especially ultraviolet B, on conidial germination and mycelial growth of grape powdery mildew. European Journal of Plant Pathology, 102 (5): 441-449.

Citation: Abebe Assefa, AmsaluGobena, "Review on Effect of Light on Disease Development and Management of Horticultural Crops under Protected Cultivations", International Journal of Forestry and Horticulture (IJFH), vol. 5, no. 3, pp. 5-18, 2019. Available: DOI: http://dx.doi.org/10.20431/2454-9487.0503002

Copyright: (C) 2019 Authors. This is an open-access article distributed under the terms of the Creative Commons Attribution License, which permits unrestricted use, distribution, and reproduction in any medium, provided the original author and source are credited. 